\title{
Mango Trees, Offices and Altars: The Role of Relatives, Non-governmental Organisations and Churches After Rape in Northern Uganda
}

\author{
Holly E. Porter
}

Fellow, London School of Economics, London, UK h.e.porter@lse.ac.uk

\begin{abstract}
This article reflects on why so many women never access justice or take advantage of available services after rape in northern Uganda. It focuses on roles of three prominent non-governmental actors: lineage-based kinship authority, churches, and nongovernmental organisations examining the parts they played after 94 instances of rape in this study and more broadly, how they have shaped notions of rape and appropriate responses to it. Evidence from this study (participant observation over three years and 187 in-depth interviews) suggests that although non-governmental organizations and churches have impacted evolution of social norms, reactions to wrongdoing are primarily decided by extended family structures, and are subject to a primary value of social harmony.
\end{abstract}

\section{Keywords}

rape - justice - transitional justice - social healing - northern Uganda - Acholi kinship

The woman sitting in front of me seemed hollow. She sat hunched over, almost as if her drawn-in shoulders could protect her heart. "I was raped four days ago", she said. The man who raped her was her late husband's nephew.

1 The quotation is from the woman whose story is narrated in this section.

(C) HOLLY E. PORTER, 2015 | DOI 10.1163/15718115-02203002

This is an open access article distributed under the terms of the Creative Commons Attribution-

NonCommercial 4.o (CC-BY-NC 4.o) License. http://creativecommons.grg/licepses/by-nc/4.0/m04/26/2023 02:57:36PM 
He resented her presence on 'his' family land. Her husband had died years before, and since she had been married traditionally, she still belonged to his family under the care of her brother in-law, and was entitled to use and benefit from family land. Her nephew is well-known in their village to be HIV positive. She narrated how four days earlier he knocked down her door in the middle of the night and said "Since my uncle your husband is dead you should go and join him. I'm going to infect you now", and then raped her. She reported him to her in-laws and called her brothers who gathered under a mango tree for a joint family meeting to decide how to handle the incident. Their decision was to take her for an HIV test. Post-exposure prophylactics would have been more appropriate given his status. If anyone had known that an international non-governmental organisation (INGO) had a centre nearby and hotline that could have made these potentially lifesaving drugs available to her, she would have had more peace of mind. Instead she was told to come back after three months when the virus might be detectable in her blood. In regard to the perpetrator, they decided to admonish him, strongly. He disappeared after the meeting. She told me how she was struggling to sleep in a hut alone, not knowing his whereabouts and feeling deeply unsafe. Women from her church came to pray with her and she felt slightly more comforted. She wished her relatives had involved police. If it were up to her, she said, he should be imprisoned. "But", she explained, "I didn't tell the police. I told the home people and they decided to settle it that way. I have to accept it because I can't decide anything like that alone".

Her lamentable situation highlights common dynamics that exist after rape in northern Uganda. Non-governmental organisation (NGO) services were available, yet unutilised. The church offered consolation to her, but played no tangible, practical role. Her relatives made a decision in the interest of social harmony, contrary to her own wishes. She was resigned to the situation, because in the aftermath of crime such as rape, no good Acholi would pursue justice alone.

This article has specific emphasis on response to rape. It looks in depth at experiences of women who were raped revealing the importance of social harmony. Interpretations of their experiences are based on eight years of living in northern Uganda, 187 interviews with a random sample in two Acholi villages conducted between 2009 and 2011, as well as ethnographic data collected over the same period. In this study, it was found that out of a total of 187 women interviewed in the two villages, 76 (just over 40 per cent) had been raped, some of them in more than one situation making a total of 94 different rape situations. ${ }^{2}$

2 Rape is not an uncomplicated category. A full discussion is beyond the scope of the article, but in brief, in this study, a situation of rape represents sexual intercourse that was without 
These rapes were perpetrated by civilians as well as combatants in the war between the Lord's Resistance Army (LRA) and the Government of Uganda.

A word on the rationale of examining together crime perpetrated in the context of war by combatants and crimes committed by civilians under more ordinary circumstances is in order. This contrasts with a trend in scholarship dealing with issues of transitional justice where distinctions between "ordinary" and transitional justice tend to be drawn sharply. ${ }^{3}$ Times of war are different in many ways from more "ordinary" times, but that does not necessarily mean that the subjective experience of wrongdoing and what are considered appropriate responses to it are also marked by the same dividing line. In the case of Acholi women in this study who were raped, at least, this is not the case. Evidence from this study suggests that there are fundamental, highly contextual ways that notions of crime or wrongdoing, and therefore appropriate responses to it, are conceptualised by people in Acholi (and, as others have pointed out, elsewhere as well), ${ }^{4}$ and these ways predated the long and vicious war from which Acholi has recently emerged. With this in mind, it is of great value to seriously examine crimes and their redress in ways that do not see the crimes of war as divorced from the rest of lived reality.

In the individual interviews, all women were asked to whom they would go if they experienced the kind of violence we had been discussing (forced sex). The following figure shows their responses. Some mentioned several categories of actors, so the figure indicates the number of times a category was mentioned (see Fig. 1).

In addition to the hypothetical question asked to everyone charted above, the women who shared having been raped also narrated what actually took place after they were forced to have sex (in 94 situations of rape) (see Fig. 2).

consent or took place in circumstances that were coercive by a woman's own assessment. It follows and builds upon, the established practice in feminist literature of privileging a woman's account in understanding sexual violence that she has experienced. See M. Hawkesorth, 'Knowers, Knowing, Known: Feminist Theory and Claims of Truth', 14:3 Signs (1989) pp. 533-557.

3 K. Muddell, International Centre for Transitional Justice, Program Report: Gender Justice $<$ ictj.org/news/ictj.org/news/ictj-program-report-gender-justice $>$, visited on 22 February 2013 .

4 See L. Viaene, 'The Internal Logic of the Cosmos as 'Justice' and 'Reconciliation': Micro-Level Perceptions in Post-Conflict Guatemala', 30:3 Critique of Anthropology (2010) pp. 287-312; R. Shaw. 'Memory Frictions: Localizing the Truth and Reconciliation Commission in Sierra Leone', 1:2 International Journal of Transitional Justice (2007) pp. 183-207. 


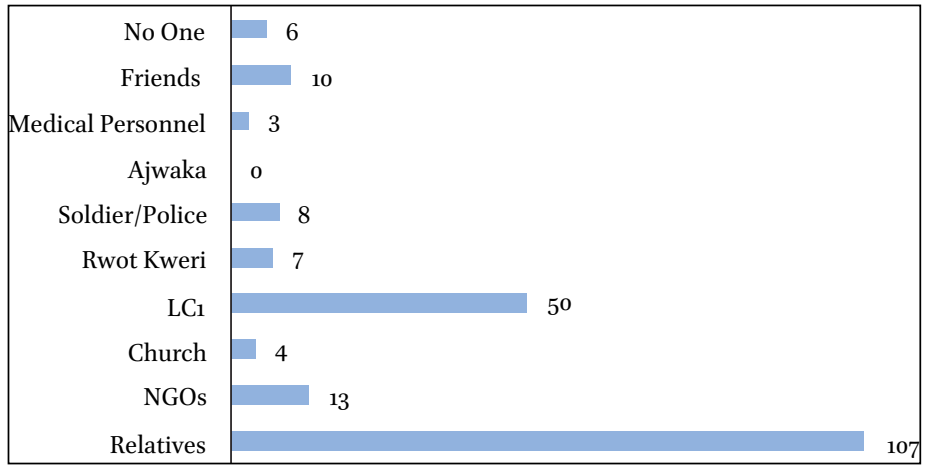

FIGURE 1 Actors women said they would involve

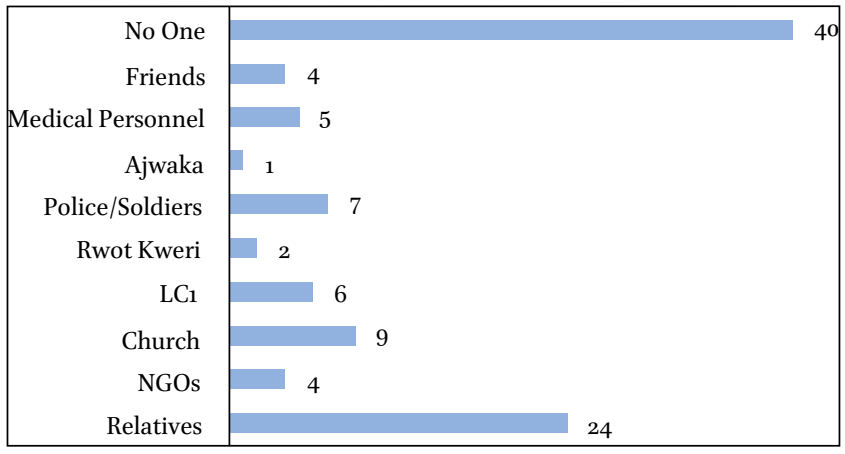

FIGURE 2 Actors actually involved in rape

Although numbers of responses are different, visually the difference between what women said they would do and what they actually did after rape is striking, especially how few said they would tell no one and how many actually remained silent. Much of the rest of this article explores why.

The following sections elaborate the roles of relatives, NGOs and churches. For each group, the article looks first in detail at practical ways these actors were - or were not - involved in the aftermath of specific situations of rape that form this study. Secondly, it examines how they have influenced notions of rape, appropriate sexual behaviour, and responses to crime. This examination of their roles as shapers in attitudes and practical actors after crime perpetrated by civilians and combatants alike contributes to a more grounded understanding for scholars and practitioners in the fields of gender-based violence, access to justice, and transitional justice. 
Relatives continue to play both the most practical and most common role in the aftermath of rape, as well as exerting considerable influence on notions of rape and redress. Because of their importance in the aftermath of rape for women in this study, the role of relatives is looked at in some detail. Several dynamics of relatives' role are apparent. First, women have situated freedom within a social system that highly values social harmony. The tendency within such a system is to 'seal' or deal with the situation expeditiously. This can take different forms, depending on the perceived threat of the crime or wrongdoing to social harmony. As some examples provided below describe, there are situations where punishment protects social harmony. ${ }^{5}$ When it does, communities find satisfaction in meting it out to perpetrators. Secondly, the context for acceptable and unacceptable violence against women is highly impacted by communal exchange of customary payments and bridewealth. Lastly, the strength of the kinship system has been weakened by the confluence of changes ignited by war and modernisation. ${ }^{6}$ What this has meant for women has been mixed. It has created more space for individual freedom and understanding of rights. Worryingly, however, it means the most practically present actor's authority has been eroded. Social protection that relatives are meant to provide, in the ideal Acholi situation, has been and is being undermined before any other sufficient replacement is established.

\subsection{Relatives' Practical Role after Rape}

A common Acholi saying is, Rwodipa mon pe, meaning "women have no chiefs". What women do have are husbands, brothers, fathers, uncles, brothers-in-law and fathers-in-law. The particularities of the situation and personalities involved determine which relatives and how distant, might be part of determining 'the way forward' after rape. In most situations when relatives were involved it was 'finished gang gang' or 'finished down home', through punishment, shaming, cleansing, payment, marriage, or some combination of these.

In Acholi when there is a problem within your house, a woman will always go to her eldest brother-in-law and then he will call her and her

5 H. Porter, 'Justice and Rape on the Periphery: The Supremacy of Social Harmony in the Space Between Local Solutions and Formal Judicial Systems in Northern Uganda', 6:1 Journal of Eastern African Studies (2012) pp. 81-97.

6 L. Hovil and M. C. Okello, 'Confronting the Reality of Gender-Based Violence in Northern Uganda', 1:3 International Journal of Transitional Justice (2007) pp. 433-443. 
husband and talk to them. After he fails to resolve the problem, then he will involve their fathers to come and talk about it. How good it [the decision] is, I mean whether it is good for the women or not, depends on the character of the brothers-in-law. If they are respectful and trustworthy, it might be good.

This woman described the norm of what women did if they chose to tell anyone about the rape they suffered, especially at the hands of their husbands. She gets at the heart of the issue when she indicates that the result for women varies widely depending on the character of her relatives. In instances of marital rape, most women ( 32 or 80 per cent of them) had not discussed it with anyone apart from their husbands. However, eight (2o per cent) women raped by their husbands sought social support, sharing the intimate violence of their husbands with others. In half of these cases, it was to seek advice from their aunts, co-wives, mothers or sisters. They distinguished this from 'reporting', as they did not expect action to follow from consultation with 'their fellow women'. The other half reported their husbands and hoped for action. All (four) of these instances were when sexual violence was one of many abuses they suffered at his hands. These exceptions highlighted the potential of the kinship system to protect women if elders are respectful of their rights. One woman had been violently forced by her husband to have sex after a serious disagreement. She told her brother and the man's elders, who then 'warned him seriously' and he reportedly never did it again. Likewise, the other was said to have reformed or at least temporarily improved after his brothers and father admonished him.

In the other instances, elderly relatives and in-laws supported women to separate from their sexually-violent husbands. This was the case when sexual violence was combined with other serious behaviours such as severe alcoholism, obvious neglect, extreme violence, or sexual conduct that drastically raised the risk of sexual diseases at home. Brothers of the man in question knew that if their brother's behaviour caused illness and eventual death, the responsibility to care for orphaned children would fall to them. In one instance when stern warnings from in-laws failed, the woman was even allotted nearby clan land and her brother-in-law acted as male provider and protection for her family, much as if her husband had died.

Unfortunately, not all women had relatives that acted in their interests. Many more anticipated that they would not and so were convinced there would be no benefit of telling anyone. Out of 94 different situations of rape my informants shared with me, 40 of them had never told anyone else. Many of them gave explanations similar to this woman: 
I do not tell anyone about this thing. Even if I went to elders they would ask me 'what brought you to this home? When you get married that's what you're there for-to sleep with him.' So I have that shame. They'll just tell me it's my duty.

Talking about her relatives, another woman explained, "it will just cause more problems if you tell someone who can't understand". In some cases, telling a relative did bring more problems, such as when a young girl's father entered her hut after a man had raped her. Rather than consoling her, he beat her for promiscuous behaviour.

At times relatives encouraged or coerced (or some variety of social and economic pressure in-between) the girl/woman into marrying against her wishes. The story below is illustrative. The girl was raped when she was still a teenager after a man and three of his brothers grabbed her on her way home and locked her in his home.

When it happened I told my mother what had happened and she went to school and reported the case. They gave him a big anthill to dig up. That was his punishment. His father was a policeman, so he hid his son's case. So they took it to the rwot kweri's [a community leader's] home. ${ }^{7}$ When they reached there, they set a date in which the boy and his father were to report and the amount of money they should pay, but they did not show up. When we tried to follow up with what happened, the father of the boy and his son went to Kampala.

It happened again when he came back from Kampala. I had gone to my auntie's place in town since she had delivered her newborn baby and I went to help her. On my way back I saw him on the road and he grabbed me and dragged me all the way up through the grass and to his home and that's how I started my marriage. I just stayed in that home. After I'd stayed at his home for two nights, I escaped to my sister's home. But my sister's husband took me back to him and said that I should stay there. When my parents heard about it, they came and took the things I was

7 In the past, and in some locations today, Rwot kweri or "chief of the hoe" is a title given to the man in a village that organises communal farming and is involved in dispute resolution. The origins of the rwodi kweri (plural) lie in the colonial period though they were initiated by Acholi people. See F.K. Girling, The Acholi of Uganda (Her Majesty's Stationery Office, London, 1960) p. 193. Their authority is over residents in a particular geographical location as opposed to a clan or kinship group. See H. Porter, After Rape: Justice and Social Harmony in Northern Uganda (PhD Thesis, London School of Economics, 2013) pp. 114-116). 
bringing them from my auntie's place. They said since it was the second time we had slept together, so they couldn't remove me and bring me home again so I should just stay.

The war disrupted social protection in dramatic ways. The level of insecurity and circumstances into which it thrust people exacerbated weaknesses of the system. Thus, although relatives are still most prominent actors in women's lives in the aftermath of rape, they act with diminished power and often within limited and weakened wider social networks. As in this situation, relatives were involved but were unable to act effectively on her behalf. Further, the social authority of the rwot kweri that would have compelled the man to appear in his 'court' had been undermined allowing him to escape judgment in the city. When he returned and raped her again, her family felt no other options were available but for her to marry him.

An important aspect that emerged from listening to stories of women who had been raped are the considerations that relatives deliberate as they determine a way forward after rape. They have multiple concerns about consequences of sexual violence and appropriate responses to it, including effects on social harmony, fertility and children (if they are involved), and, importantly, the expected cosmological consequences. The location of where sex occurs, consensual or otherwise, is important in Acholi understandings of illicit and acceptable sexual behaviour. Sex 'in the bush' or near water is considered particularly dangerous. A girl who had been raped by a neighbour explained: "It happened by the well here [she pointed in the direction of the well] and I told my parents, and they said I should be cleansed and leave alone the rape case or taking it to a court. It is because it happened in the wrong place". It was more important to deal with possible consequences of committing an abomination/taboo (kiir) of sex near a well than to hold the boy accountable for his crime.

Women who had been raped 'in the bush', in a garden, or near a well whether by rebels, soldiers or non-combatants - had fears of cosmological consequences. All sex that happened in the context of the LRA, even if it occurred within huts in the more permanent LRA camps, is considered to have taken place in the moral space of 'the bush'. In the context of the northern Uganda war, fighting in the bush, displacement and the practice of night commuting all provided many more opportunities than usual for sex in the wrong places to happen.

After rape in the context of 'forced marriage' in the LRA, women were rarely afforded the option of keeping their experience secret. Usually, their abduction was well known. Relatives, neighbours and extended social networks 
assumed they experienced sexual violence while in captivity. Often they returned with children and sometimes resultant health problems.

Most LRA who raped women were either still in the bush or dead. A few returned and received amnesty. The strong reaction of many civil society actors after the intervention of the International Criminal Court (ICC) in $2005^{8}$ could be interpreted as a version of the extended family role of 'sealing' the issue within themselves by responding to LRA violence in the interest of social harmony, trumping concurrent individual belief that wrongdoing deserves to be punished.

\subsection{Relatives' Role in Shaping Ideas}

Notions of appropriate sexual behaviour and, therefore, what constitutes sexual crime are deeply impacted by one's relatives. Many women who were raped by their husbands or who began their marriage after someone forced them to have sex had similar sentiments as this woman:

You just tell yourself that maybe this is a normal way of settling in a home. It was like that [forced] my first time and I was annoyed and depressed at first but I realised that it was also my fault because I am the one who accepted going to his house.

My informants told me that long ago, close female relatives, usually aunts, were meant to teach girls about what to expect when they 'went to a man's home', that is, when they got married and began a family. But as noted, the kinship system has weakened. Many young people are growing up without strong input from extended kinship networks. Practices that were common in the past have diminished and much of what could be understood as sexual education happens in unintentional ways, more by osmosis than by deliberate impartation of norms. ${ }^{9}$ One result is that many women are unprepared for their first sexual encounters. Women who reported that their first encounter was forced, said it was in part because they simply lacked awareness of what to expect from man and woman's bodies meeting. One woman who married at thirteen elaborated:

8 See e.g., Civil Society Organizations for Peace in Northern Uganda, The International Criminal Court Investigation in Northern Uganda (CsOPNU, Kampala, 2005).

9 H. Porter, 'Avoid Bad Touches: Schools, Sexuality, and Sexual Violence in Northern Uganda', 41:1 International Journal or Educational Development (2015) pp. 271-281. 
I had no idea what he should've done differently because I was so young, thirteen by then. I didn't even know those things happened. All I knew is that when women go to a house with their husband they stay together and you cook, eat, have kids, but I didn't know about details of sex. If someone had taught me I would've gone to him prepared, but I had no idea about what would happen.

An important aspect of relatives' contribution to notions of appropriate and unacceptable sexual behaviour is how they shape the understanding of consent. Most women, though not explicitly taught, come to understand that a good Acholi girl should refuse and even fight the first time they have sex, regardless of desire. In this context, ascertaining consent is complicated, and how a man distinguishes whether his partner has given it or not is problematic.

Many people equate consent with going to a 'solitary place' with a man. The vulnerable position this erroneous assumption puts women in is illustrated well by the experience of a young woman raped twice by different men when they were alone. Because of this, she did not consider these instances rape, yet she said she had not wanted to have sex with them, that they forced her, and that she was deeply aggrieved. The first was a man she had begun dating but had not yet decided to sleep with. The other was a family friend. Trusting him, she assumed when he invited her to his house that he had something important to discuss with her. Instead he drugged and raped her. In both cases, she told no one about what happened because of her notion of consent.

But perhaps the most crucial way in which relatives impact ideas around sex, sexual violence, and about the right way forward in its aftermath is through social agreements that are formed through the exchange of $l u k$, customary payment related to sex, and to bridewealth. During the war, many girls and women were abducted by the LRA, raped 'in the bush', and forced to act as 'wives' to designated men. They have been referred to as 'sex slaves', but they were also expected to cook, clean, garden, and bear and raise children..$^{10}$ It would seem that life as a forced wife might not have been drastically different

\footnotetext{
10 S. McKay and D. Mazurana, Where are the Girls? Girls in Fighting Forces in Northern Uganda, Sierra Leone and Mozambique: Their Lives During and After War (International Centre for Human Rights and Democratic Development, Montréal, 2004); K. Carlson and D. Mazurana, Forced Marriage Within the Lord's Resistance Army, Uganda (Feinstein International Center, Tufts University, Medord, MA, 2008).
} 
from lives of girls and women abducted and forced into marriage by noncombatants. Scholars working in other areas have noted the plight of war victims and women harmed by forced sex in their own homes and communities was at least qualitatively similar.11 There are however, distinct and significant differences in the harm they experience. ${ }^{12}$ One is worth mentioning here. It is related to the connection between customary payments and social permissibility of violence against women and girls.

Acholi language and represented attitudes around bridewealth and women's place in a family is often tied to notions of property rights. Adultery or rape of another man's wife can be understood as a trespass on his property. This idea, is not new, or unique to Acholi. Other commentators have noted a number of analogies between theft, trespassing, and other property laws and laws pertaining to sexual violence. ${ }^{13}$ Similarly, many women in this study who recalled confrontations with their husbands about his sexual violence toward them were given the excuse that his father's cows purchased them and as long as they are wives, husbands should 'have access'. There are many ways to refer to the man one lives with or to the father of one's children. The direct word for 'husband' cwara can be used, but it is less common than 'the father/owner of my child', won latina. ${ }^{14}$ Their husbands insist that after payment of bridewealth their bodies ceased to be their own, and they have no right to refuse access to 'the owner' (see Fig. 3).

I point out this metaphor between property and sexuality with some pause, and wish to add an important caveat, because if understood in isolation, it risks painting a distorted picture of what I have come to see as deeper meaning behind bridewealth for many Acholis. Although for some, it may be related to notions of individual property rights (as values of individualism are being imported and assimilated, the idea of women as personal property seems to go hand in hand), in general, it is better understood as akin to establishing social belonging. It has to do with social order, identity, entitlements, protection and responsibility. The above common saying in Acholi points to a conscious belief

11 C. Nordstrom, Girls and Warzones: Troubling Questions (Life and Peace Institute, Ostervala, 1997).

12 H. Porter, 'After Rape: Comparing Civilian and Combatant Perpetrated Crime in Northern Uganda', Women's Studies International Forum (In press).

13 S. Estrich, Real Rape (Harvard University Press, Boston, 1987); L. Clark and D. J. Lewis, Rape: The Price of Coercive Sexuality (Women's Press, Toronto, 1977); P. Bart and P. O'Brien, Stopping Rape: Successful Survival Strategies (Pergamon Press, New York, 1985).

14 P. J. Crazzolara, A Study of the Acholi Language: Grammar and Vocabulary (Oxford University Press, London, 1938) p. 418. 
Iwila ki lab lyec?

Did you buy me with elephant tusks?

A rhetorical question used by wives who are mistreated by their husband to draw a distinction between slaves, who were bought with elephant tusks, and wives for whom brideprice is paid.
FIGURE 3

of the difference between wives and property. The idea of ownership is still in play, but as with other understandings of property rights in this context, it is communal. Sexual transgression, then, is a trespass not only on an individual man's property, but against social foundations of Acholi society. Because this belonging, established through payment of bridewealth, is so critical to social harmony, unless sexual violence, which conforms to it, is extreme or coupled with other types of socially unacceptable behaviour, much violence, including marital rape is ignored or effectively condoned.

A crucial social distinction concerning a woman who was abducted by LRA and forced to become a 'wife' in the bush is that the man in question did not enter into a social contract with the woman's family, nor involve her relatives in her selection or negotiating bridewealth or other payments. Thus an LRA 'husband' was related to her in ways that were outside of Acholi social norms. The sexual violence and forced marriage she endured broke conventions of interacting between men and women, and is therefore experienced as a crime or wrongdoing perpetrated against both her family and his; indeed, it is against Acholi identity.

Women often talk about being married 'to a home' rather than being married to a man. If a woman married traditionally (nyome), and all customary payments such as luk and bridewealth (lim akumu) were paid, she and all of her children belong to the man's family and wider clan by virtue of their contribution of cattle, money or other items given to her family. Before war and displacement, both individual families and wider kinship groups typically had more resources - including cattle which were almost all lost during war - both to pay and to refund bridewealth. Many women today are in 'their homes' - that is the man's family home - but are not nyome, meaning that no bridewealth has been paid. What this means in practical terms is that she has more freedom to 
leave, but less social protection from her own relatives and her in-laws, another example of how the strength of kinship systems has been undermined.

On the other hand, women who have been married with payment of bridewealth might (depending on the character of both his family and clan, and hers) have greater social protection. The ownership or social belonging established through customary payments can work in her favour. It gives her husband's extended family more authority to intervene on her behalf if her husband mistreats her. After all, he is mistreating 'their' wife. They contributed financially to bring her into the family and they have a stake in her well-being. It can, and does in some instances, work against her interest, keeping her in a position where she is at risk to violence, unable to leave without refunding the payments, which her family may be unable or unwilling to do. Given current economic constraints, many families are unlikely to be capable of refunding bridewealth making many women less able to leave sexually violent marriage. In sum, a woman is largely at the mercy of the particular ethical attributes of her in-laws and good hearts and economic ability of her parents' kin.

We used to follow the culture that we had in the olden days, but now we women are realising that we have rights and anything that oppresses us we don't accept. You see, that's why I have separated [from my husband]. The way I found out that I had rights is through the radio and also because of being in the [internally displaced persons] camp. NGOs used to call gatherings and talk to us about women's rights.

Based on information provided by women in this study, NGOs' role has several dynamics. First, rape, is something that NGOs teach should be considered a violation of human rights and be reported, with some action to follow. Secondly, among women interviewed, many expressed their belief that NGOs could be trusted to uphold their interests, in contrast to governmental authority, which they often deemed corrupt and inefficient, and relatives or traditional authority that were commonly perceived as not sharing a progressive understandings of rights and their own evolving concepts of gender. Despite this, few benefit from existing services because of lack of awareness combined with strong social constraints and the diminished yet still paramount role and priorities of relatives in decision-making.

When asked where they would go for help if someone committed a violent crime against them, many women answered similarly to this woman: 
I heard that there is some group of people that are helping women, but because I'm not educated, I don't know the name of that group. I hear they stay in town. I heard they're from other countries, but I don't know.

A few had slightly more specific knowledge, saying they would visit the 'people of human rights' and that, 'all NGOs are human rights people'. A few described the location of a particular Ugandan NGO in Gulu town commonly referred to as 'the people of human rights'. Knowledge of what NGO services are available and how to access them is low. Even where knowledge exists, very few women take advantage of opportunities. The following section looks in greater detail at how NGOS were involved in the aftermath of rape of women in this study.

\subsection{NGos' Practical Role after Rape}

In northern Uganda the influx of NGOs during the war resulted in a high level of activity aimed at the prevention and response to gender-based violence (GBV). Child protection committees and GBV committees were formed and continue to exist in all sub-counties and most parishes in the Acholi subregion. Trainings were conducted for police, the judiciary, 'traditional' leaders, teachers and other parties identified as 'stakeholders' in the protection of women. Lay counsellors have been trained, sometimes in case management. There is an operational hotline to report instances of sexual violence and centres where services can be accessed. Services have been mapped and referral pathways have been written for most sub-counties. A lead NGO has been designated in each sub-county to partner with local government authorities to prevent and respond to GBV. Ideally, through these pathways, services flow down and information flows up.

Despite this flurry of NGO efforts in the region, and specifically in the two villages where this study was conducted, only four women had any interaction with NGOs after they were raped..$^{15}$ Of these, two women had been raped within the LRA and talked positively about the assistance they received from a reception centre after their return. One of them said:

What has helped me is that when I was in [the reception centre] those people helped me with counselling. Not only that, they took me to the

15 Likewise, the SWAY research found that when female youth are physically threatened in the community, less than one percent seek assistance from an NGO or health care worker or a member of the Ugandan armed forces. See J. Annan, et al. The State of Female Youth in Northern Uganda: Findings from the Survey of War Affected Youth (sWAY) (Feinstein International Center, Boston, 2008) p. viii. 
hospital and I had the bits of bombs and a bullet that were in my body removed. I was also given tests and treatment and I left there healthy. Then they inquired my interest, since I didn't have access to education and I chose tailoring and they trained me in that. They didn't have a sewing machine to give me then, so I went home and I would begin thinking that I should do something even if I can't be educated, and I managed to struggle to buy my own machine, and even today I have some good customers and I get at least a little money and it's sustaining me.

The other two had been raped by their husbands and tried to access services from NGOs. One went to a Ugandan NGO, but according to her, they did not help. The other reported to a 'group that helps women', which I found was the child protection/G BV committee for her area. They wrote a report documenting her problems with her husband, which included sexual violence as well as serious neglect. She expected their report to be followed by action. When it was not, she sought help from her relatives mediated by the Local Councillor to separate from her husband, which she eventually succeeded in doing.

Some women in the more remote of the two villages where this research was done mentioned an INGO, and their trained lay counsellors, as being helpful in the event of rape. But none of the women went to the centre or to the counsellors after rape. Some said that they have visited the centre for other reasons, such as their husbands beating them seriously.

A woman whose husband rapes her commented on why:

We have people like [the INGO] and also the people of human rights. They might help in a difficult situation or your conflict. But with problems like mine [a sexually violent husband] of course they can't help. If there are issues in the home you settle it between the two of you or you can call in the brothers of the husband, but if it passes them then we call family elders.

Even when the sexual violence occurred with people other than their husbands, relatives and elders were the primary sources of decision-making on responding to rape. ${ }^{16}$

16 One study also showed that NGo's services, e.g. health services, tended to focus on sexual violence from a stranger and not overwhelmingly more common forms of sexual violence such as intimate partner violence. See M. Henttonen, et al. 'Health Services for Survivors of Gender-Based Violence in Northern Uganda: A Qualitative Study', 16:31 Reproductive Health Matter (2008) pp. 122-131. 
Women in this study who were raped by combatants, with the exception of the two above who passed through a reception centre, were unaware of how NGOS or other actors might benefit them. They were equally unaware of the possibility and policy discussions that were taking place at the time of writing regarding reparations.

Reparations efforts have limited scope thus far in providing any individual redress even in the most straightforward and obvious ways - even more so, the more complicated and delicate nature of reparations for sexual crimes. One woman who had been deformed by a bullet wound and also raped commented that although she hadn't received reparations for either injury, the harm of her sexual violence could not be photographed and thus her invisible wounds would be impossible to compensate. The reparations measures to be put in place, among other transitional justice mechanisms, remain in their initial stages in northern Uganda. The ICC's Trust Fund for Victims (TFV), at the time of writing had been one of the only actors on this front and was supporting a program of gender-based violence response run by an NGO. However, the violence the program responded to was current and perpetrated by civilians. It was not war-related crime within the jurisdiction of the ICC outlined in the Rome Statute. ${ }^{17}$ This begs the question of why the TFV was not operating more squarely within its mandate. Perhaps, it is in part because of the way the TFV works, through NGO partners. NGOs in northern Uganda have largely recognised that singling out particular categories of people for assistance, rather than using a more needs or rights-based approach is counterproductive and creates new problems. This recognition is welcome and indicative of wider learning amongst NGOS. However, the TFV is not an NGO. It is meant to be about justice after crimes against humanity, not, "a donor of last resort", which is how a TFV staff in Uganda described their funding approach. According to a former staff of TFV, there has been much soul searching about such issues within the TFV, but more is needed if it is play a normative or reparative role for victims of sexual crime within the jurisdiction of the court.

Another often-cited issue with respect to sexual violence and reparation efforts (particularly the TFV) is the difficulty of knowing exactly how to identify victims and how to design targeted assistance to women whose rape would be counted among crimes of concern to the court. Evidence from this study is suggestive of material ways reparations could respond to harm of rape. Others

17 This information is based on conversations with the head of the Trust Fund in Uganda as well as the then project coordinator of the NGO during the ICC Review Conference in June of 2010, a former staff person in January of 2013, and the consultant who evaluated the NGO in March of 2013. 
working on representing victims' views regarding reparations have highlighted some of these which resonate with many of the sentiments expressed by my informants, particularly health, education, housing, land inheritance, rebuilding livelihoods and proper treatment of the dead. ${ }^{18}$ The current study also reveals that women who have been raped can be identified and are often willing to self-identify for assistance. Many women I spoke with expressed sentiments similar to the woman with the bullet wound above: "Everyone knows what happened to me. Why should I be afraid to come forward if it can help me?"

\subsection{NGos' Role in Shaping Ideas}

Radio and other mediums of exposure to ideas about violence against women and women's rights have impacted the way women think about their own experience of sexual violence and what appropriate responses to it should be. The idea that 'rape never used to be there' is not an uncommon response when I tell Acholis about my research. I have found that what is meant by this statement is usually one of two things. First, the notion of rape as a crime as it is talked about by NGOs did not exist prior to the war. An example is the reaction of one of the eldest women I interviewed. She did not know her age, but made references to colonial legislation around the time she was married that would indicate she must have been around a century old. She laughed at my questions and said they were "very useless" because, as she expressed, "it is hard to even say whether a man forced you to have sex when you never even thought that refusing was an option and you were never asked if you agreed". Another elderly woman also laughed and had the same opinion of my queries being 'very useless'. Her explanation was that she and her age-mates did not know what 'rape' was in those days, although, she added, of course, men used to force them.

The other meaning of the idea that 'rape never used to be there' is driven by values associated with Acholi identity and a vision of a kind of continuous past, a static and ideal picture of how Acholi society is at its best and all social protections are functioning as they should. It is less a statement of understood reality and more an expression of Acholi values and ideals, a 'benign' patriarchy (if that were possible) - Women should be protected from sexual violence and it should not happen if all is healthy in the community.

These notions have been dramatically impacted since war and an influx of NGOs. In Acholiland, there are few places that remain untouched by NGO

18 unohchr, "The Dust Has Not Yet Settled:" Victims Views on the Right to Remedy and Reparation. A Report from the Greater North of Uganda (Kampala, Uganda, 2011) p. 81. 
interventions, and certainly by radio airwaves. Although many Acholi women talk about rape as something 'normal' or gin matime (literally, 'something that happens'), they equally talk about it as morally wrong with negative impact on their relationships, mental health and bodies. When asked how they came to this understanding, radio and NGOs were the most common responses.

One woman commented on how she viewed changes in the way people think. Her own experience with sexual violence had been severe. She was abducted and spent five years as a forced 'wife' in the LRA, only to survive a second sexually violent marriage before she settled with a man who treats her well.

In case the girl changes her mind after she has gone somewhere alone with the man, but she's embarrassed to scream, she will show that she's very annoyed and also fight him. Sometimes she'll end up giving in because he overpowers her, but afterwards she'll sack the boy. And in today's situation she can even take that person to court. In the past people were ignorant of their rights. But today with sensitisation of NGOS, people know their rights. Not only that, in the past the issue of age brackets wasn't considered. It was just whether the girl has breasts or not. Now it's if someone is under 18 they are considered children, and so if someone sleeps with them the person can be taken to court. But in the past, the girl could report to her parents and from there the parents would go and talk to the parents of the boy and sometimes they would have to make a payment called luk. $L u k$ doesn't mean they have to stay together necessarily, but in some cases they do get married. Either way, that payment, luk, would need to be paid.

The idea that a girl who was unhappy about a sexual encounter could sincerely fight or 'sack the boy' would not have occurred to many of my elderly informants in their youth. Even though virtually none of the women in this study accessed legal avenues of redress, the knowledge that laws are part of what defines appropriate sexual behaviour and how is a recent phenomenon that is attributed to NGOs. The idea of sexual violence has evolved from only a social crime as the discussion of luk indicated, to a crime that also abuses rights of an individual that should be protected by the state.

Evidence from women in this study suggests that NGOs have had an impact on notions of rape and appropriate responses to it. They have contributed to a growing sense of individual rights which women feel are violated by being forced to have sex, even by their husbands. It also shows the limits of NGO impact. Despite the fact that the majority of women said that they trusted NGOS 
to help them and many said they would turn to an NGO for help after sexual violence, only four actually did and just two of those felt they were helped in a meaningful way. Women's experiences point to two main contributors to this state of affairs. First, many, especially in rural areas, are unaware of how or if NGO services are relevant to their needs and situation (sometimes they are not). Secondly, and the much greater challenge, is that decisions surrounding how to respond to crime are made within the context of extended family structures and with the supremacy of social harmony as a driving factor. NGO programs tend to target women as individuals in their gender-based violence response programs and have the supremacy of human rights as a driving factor.

\section{$4 \quad$ Churches}

The backdrop to debates surrounding justice after crime in northern Uganda has been a narrative of forgiveness over punishment. Links have been drawn between religious understandings of forgiveness and Acholi cultural values by prominent religious leaders, especially as they had been active, over many years, in attempts at peaceful resolution of the war. Other more political actors, the Acholi cultural organisation, Ker Kwaro Acholi, and some NGOs who had advocated for the Government's Amnesty Law, have joined them. These links are also what many of these leaders believed would best contribute to peace for their people.

Research for this study indicates that the concept of forgiveness taking precedence over punishment in situations where this is thought to lead to social harmony has found fertile ground in Acholi soil. It is evident in the aftermath of rape by combatants and civilians alike. Social harmony and family unity are principles that the church (Anglican, Catholic and Pentecostal) and many Acholi believers who are raised in their sphere of influence hold dear. This is usually coupled with a low expectation of justice in this life and a strong belief that, in the end, God will judge. One woman expressed a common sentiment:

It's difficult because you don't know if those men [members of the LRA] are on the government side now or if they are dead or they are still in the bush. Because you can't arrest them and don't know where they are. I think that if I was the judge I couldn't give a sentence. I can't say, 'let's kill them' or something like that. I would say 'let them go but let God punish them in His own way'. The Bible says do not judge. Let God do what he wants to them. From what I hear in church you don't repay evil with evil. They did bad things to me, so I should forgive them and let God judge. 
This woman had been abducted twice, spending her first period of captivity as a forced wife to a man in LRA leader Joseph Kony's own camp. The second time, in a smaller mobile brigade, different men raped her nightly until they were more settled and she was allocated to one of them. ${ }^{19}$ Another woman shared her belief in God's judgment after being drugged and then raped by a Catholic priest (the single reported instance of rape by clergy in this study).

The best punishment would be to tell his congregation and the community since that would be the worst punishment - worse than prison. He would have that terrible shame. But to me, I have already cast out my feelings to God. I didn't tell anyone. I didn't tell my parents! I didn't tell his Bishop. But what I know is that God will punish him. My strong belief is that one day, God will punish him because he lied to God, saying that he is God's worker, but he's the devil's worker. It might not be seen - but I know that something will happen to him.

The teaching of churches on forgiveness as equating an absence of any form of earthly accountability has both impacted and been shaped by a consistent and strongly-held value in Acholi culture, the supremacy of social harmony. There is resistance to exposing wrongdoing or insisting on punishment where it is thought to threaten social harmony, even when individuals involved feel strongly that punishment is deserved.

\subsection{Churches' Practical Role after Rape}

Twelve out of 94 different situations of rape in this study resulted in any type of punishment for the man. ${ }^{20}$ In a context of such limited punitive response to rape, it is no wonder that the church's primary role after rape is spiritual consolation, supporting an internal process which women have power to pursue regardless of the social constraints of relatives or impotence of formal justice mechanisms. It is interesting to note that although prayer was often seen as the only available option, it was not deemed an ineffectual or insignificant option. Rather, almost all of the women who had been raped discussed the

19 Such circumstances I have come across in my research deviate from documented norms of LRA behaviour. See Carlson and Mazurana supra note 10; E. J. Wood, 'Variation in Sexual Violence during War', 43:3 Politics \& Society (2009) pp. 307-341. That these and other similar situations occurred in my relatively small random sample of just under 200 women suggests that they may be more common than previously thought.

20

The punishments varied greatly, from digging up an ant hill, being beaten, paying a fine, or buying a goat for a cleansing ceremony, to being imprisoned or being shot and killed. 
importance of prayer in their healing process. As one woman said, "[p]rayers help me most. When I am really depressed and I pray, I feel like my heart cools down". Another woman expressed her feeling this way:

The best thing would have been if I'd reported to my brothers, but it was only that I was young and feeling so ashamed so I didn't. The brothers would have followed it up in court or to the police and arrested him. They should have made him pay some money, but all the same, I would have felt ashamed. People would have said I was the one who he slept with and embarrassed me. All I could do was pray and just leave it to God.

Some women wanted to pursue other remedies after rape, but were dissuaded by religious relatives. For example, one young woman was attacked by two men she did not know when she was still living in the camp. One held her and kept her from screaming while the other raped her. As soon as they let her go she started screaming, but they had run off before people realised what was happening. Despite her personal feeling that they both should have been imprisoned, she did not report to camp authorities or soldiers who were supposed to provide security. She explained: "I told my mother after it happened, but she was someone who is 'saved', so she told me to just leave the issue, forget about it and forgive the person. Also since I didn't know the person, I couldn't do anything". As with many women, the combination of a low expectation of justice from available options, combined with their own or someone in their family's faith, meant that forgiveness without punishment was her only option.

Besides prayer and spiritual comfort, one of the important considerations in the aftermath of rape is how to effectively deal with any cosmological consequences. There are two main ways that this is generally handled, through the church and the power of prayer and/or through cleansing ceremonies. ${ }^{21}$ The role that the church plays, apart from internal emotional and spiritual healing women seek, is decided by relatives and social consensus about appropriate response to crime or wrongdoing, as the following young woman's story illustrates. She had been raped when she was in the garden, which, as noted above is an Acholi sexual abomination. It is kiir. She explained, "I come from a Christian background and we are saved, so although some people wanted to do the cleansing my father refused. They just prayed for me instead".

21 H. Porter and L. Victor. 'Dirty Things: Spiritual and Psychological Distress and the Pursuit of Healing Amongst Ex-Combatants of the Lord's Resistance Army, Northern Uganda', conference paper (African Studies Association, Sussex, 2014). 
This young woman was having fertility problems when I spoke to her, and was convinced that these were due to not being ritually cleansed by her clan elders after being forced to have sex in the garden. Many of the women in this study who had been raped during the war were also raped in locations, which made it kiir. The issue of whether to pray or to cleanse is a common one (although they are not necessarily mutually exclusive), and manifests itself not only in individual instances of rape, but in debates about appropriate communal response after massive crime. Despite this, there has been evident synchronism in many ceremonies that incorporate prayer and even sermons into rituals.

The synchronism is not only between tradition and religion, but with what could be called 'NGOism.' Rather bizarrely, at a ceremony in which I meant to passively observe as an NGO worker in 2007, I found myself thrust into the middle of a circle of gray-haired elders and given the lead to a goat. I was instructed to 'handover' the goat on behalf of the NGO, which I reluctantly did amidst much photography. I later learned that before we arrived that day, a group of born-again Christians had a prayer meeting so that our cleansing ceremony would not open the area up to demonic activity. ${ }^{22}$ Later, I asked a retired Anglican Bishop Ochola his thoughts. He pointed out common convictions held by traditionalists and Christians such as the striking imagery of a sacrificial lamb and belief in cleansing power of blood. He suggested that the bornagain group should have joined the ceremony and opened and closed the 'meeting' with prayer. In fact, his use of the word meeting was strangely as accurate a description of what happened as 'cleansing ceremony'. There was an agenda, there was a committee who had organised it, and everyone registered on an attendance sheet.

Such experiences give pause to the desirability of NGO, governmental, or otherwise external interventions or policies that promote, control or financially support such practices. This is not because they are not valuable mediums of social (and individual) healing; in fact it is precisely the opposite. In addition to social functions they evidently play, many are strongly convinced that they have been spared negative cosmological consequences of crime because they, or the location of the crime, had been cleansed.

22 Two of us present that day have since written scholarly reflections on it. See D. Peachey, 'The Elusive Quest for Reconciliation in Northern Uganda', in N. Palmer et al. (eds.), Critical Perspectives in Transitional Justice (Intersentia, Cambridge, 2012); H. Porter, 'Locating Justice: Community-Based Approaches in Northern Uganda', conference paper, Taking Stock of Transitional Justice (Oxford Centre for Socio-Legal Studies, Oxford, 2009). 
NGO or other outside support of such practices is so troubling because it fundamentally changes the ritual and its social power. Additionally, if an NGO or outside party is known to support such practices, it undermines communities' initiative. In one of my research sites, for example, a terrible massacre took place. Residents wanted to perform a cleansing ceremony and were promised support by United States Agency for International Development to do so. Due to administrative delays, the ritual was postponed repeatedly. One might assume that financial requirements of the ritual were beyond the means of mostly subsistence farmers who live in that village, however, it is instructive to consider the resources pooled internally for last funeral rites of long-deceased. Special huts are constructed specifically to house visitors and days of continuous eating, drinking and dancing (often with hired generators and speaker systems) ensue. In the year prior to writing, several took place in the area in question, all supported by contributions made by surrounding residents. Although ritual is valued and resources could be mobilised, they are not while residents await external support. ${ }^{23}$

The relatively few NGO-supported cleansing ceremonies were among the most-widely known and promoted ceremonies for dealing with war-related violence or reconciliation for returning rebels. One of the most widely practiced public ceremonies was a relatively simple one to welcome the LRA back into the community called nyono tong gweno or 'stepping on an egg'. Even more widely known (if often misrepresented) was the reconciliation procedure called mato oput, 'drinking of bitter herb'. In addition, and with less general publicity, NGOs often sponsored local land or area cleansing ceremonies such as those discussed just above. ${ }^{24}$

23 A complicating factor is that in last-funeral rites who is responsible to host (and cater for financial and material requirements) is well established. Whereas in the case of ritual that deals with cosmological consequences that affect a host of people this is much less clear.

24 Nyono tong gweno is typically performed after long absences from home to cleanse the person upon homecoming and has been used in large public cleansing ceremonies for those returning from the LRA. Mato oput is customarily used in cases of murder or accidental death. It is the culmination of negotiations on compensation of the lost life between the bereaved and offending clan. As described, for example, see T. Harlacher et al., Traditional Way of Coping in Acholi: Cultural Provisions for Reconciliation and Healing from War (BMZ and CRs, Kampala, 2006) pp. 78-91. To my knowledge, there have been no successful mato oput ceremonies conducted with any LRA for war-related killings, although in at least two instances there were attempts to do so initiated by international agencies. The process was filmed. It can be accessed on Youtube where it is entitled: "A Heavy Matter". It was eventually aired on Al Jazeera in 2011 under the title "Bitter Root". The film glosses over a number of problems and eventually shows the mato oput ceremony though 
Conversely, ceremonies that communities organise in the absence of any policy or program have typically demonstrated much more variety. One woman described how they used to handle rape cases in her clan. It involved dragging a sheep to the location where rape took place, ritually killing it, and then smearing the victim and perpetrator with faecal matter from the intestines. Though several women mentioned similar practices having occurred in the past, none of the women in this study who had been raped had undergone this ceremony themselves. One woman described a different ceremony done for her: "Cleansing was done; they bought a goat, circled me and killed it by stepping on it repeatedly. They cut it in pieces and roasted it and then threw it in all directions".

In such locally determined and performed ceremonies, cosmological consequences of the specific situation are considered to determine the requirements of the ceremony. For example, in a case following the rape of a woman by her cousin, the consequences of incest were most important to deal with, which had little to do with the forceful nature of the act. Important considerations concerned the relationship that the man had had with the woman, where the act took place, and what if any consequences were known to have resulted. It would be a rare single approach, and an ingenious one, that could cater for all the variation needed to respond to the specific exigencies of individual cosmological and social needs through ritual without undermining meaning and significance.

Notwithstanding some pronounced tension between some religious followers and traditionalists, there is an underlying consistency in motivation which expresses widely shared belief in the need to deal with cosmological consequences of crime or wrongdoing and the view of such wrongdoing as impurity to be cleansed. They also hold a common primary aim to restore broken social harmony.

\subsection{Churches' Role in Shaping Ideas}

The church has a powerful role in shaping notions of appropriate behaviour and how to respond when moral norms are broken. Most Acholi would selfidentify as Christian (nearly three-fourths as Catholic). While the potential for positive impact is great, and there have been some recent initiatives, the church has left this potential largely untapped.

Instead churches have mainly promoted the pre-eminence of family unity and submission of women to their husbands, while not teaching men about appropriate loving and consensual sexual relationships - at least until prewedding classes before a church marriage ceremony. Weddings are a costly

it is not clear under what circumstances it took place. Ker Kal Kwaro Acholi claims an additional two ceremonies have been performed but I have been unable to trace any participants nor confirm that such a process occurred in either location to date. 
affair, and the majority of couples who go through a traditional (nyome) marriage, never also wed in a church ceremony. Those who do are usually only able to afford a church wedding later in life. Some of my informants joked that their husband had grey hair the first time he was taught that sex should be mutually agreed. Only rarely does a couple receive moral education related to marriage from a church when it has relevance to the formative period of their sex life.

\section{5}

\section{Conclusion}

Relatives, NGOs and churches have had significant impact on the evolution of social norms. However, reaction to crime and wrongdoing more generally is still primarily determined by decisions made in the context of extended family and kinship structures. Whether the perpetrator of a crime such as rape is a rebel, a soldier, a husband, a relative, a neighbour or a stranger, notions of how to maintain or restore social harmony largely determine what to do in the aftermath, trumping individual sentiments regarding what the man deserves and what the woman needs.

Despite a growing understanding of their rights as promoted and taught by NGO and human rights discourse, women still inhabit a place where social harmony is paramount. The most important thing that women need (and sometimes value) after suffering crime is still for the people who are closest to them to agree that the course of action taken after rape is appropriate.

In our tribe in Acholi here, I think settling it down at home [gang gang] is best because if you take it to another level like the Lord Councillor and police it will bring hatred between the clans, so doing things traditionally by getting elders to just warn them is good. The community seals the issue within themselves.

In the final analysis 'home people' and not 'the people of human rights' determine what justice after rape looks like. The home people typically consider cosmological consequences and the effects on social harmony as having precedence in their deliberations. An often evidently valid concern raised in regard to traditional authority is the existence of gendered hierarchies and inequalities that exist within them. ${ }^{25}$ The post-conflict moment of transition offers a

25 N. Reilly, 'Seeking Gender Justice in Post-conflict Transitions: Towards a Transformative Women's Human Right Approach', 3:1 International Journal of Law in Context (2007) pp. 155-172; T. Allen, 'Bitter Roots: The 'Invention' of Acholi Traditional Justice', in T. Allen 
window of opportunity to forge more just gender relationships. Social norms and power dynamics have been affected by war and subsequent post-conflict developments in Acholi, but the role of relatives is still strongest, and cannot be bypassed or overcome simply by strengthening other actors or by programs designed to target women as individuals. In order to maximise opportunities presented by the transitional moment that still characterises Acholi less than a decade after the guns have fallen silent in Uganda, those working on these issues will need to recognise and engage the role of extended family structures in women's lives and appreciate the deference to relatives that women are likely to continue to show while aiming to transform detrimental gender dynamics within them.

and K. Vlassenroot (eds.), The Lord's Resistance Army: Myth and Reality (Zed Books, London, 2010) pp. 242-261. 